\title{
FEV1 and FVC pulmonary function reference values among 6-18-year-old children: a multi-centre study in Saudi Arabia
}

\author{
A. Alfrayh, ${ }^{1}$ T. Khoja, ${ }^{2}$ K. Alhusain, ${ }^{3}$ S. Alshehri, ${ }^{3}$ A. Gad ${ }^{4}$ and M. Madani ${ }^{3}$
}

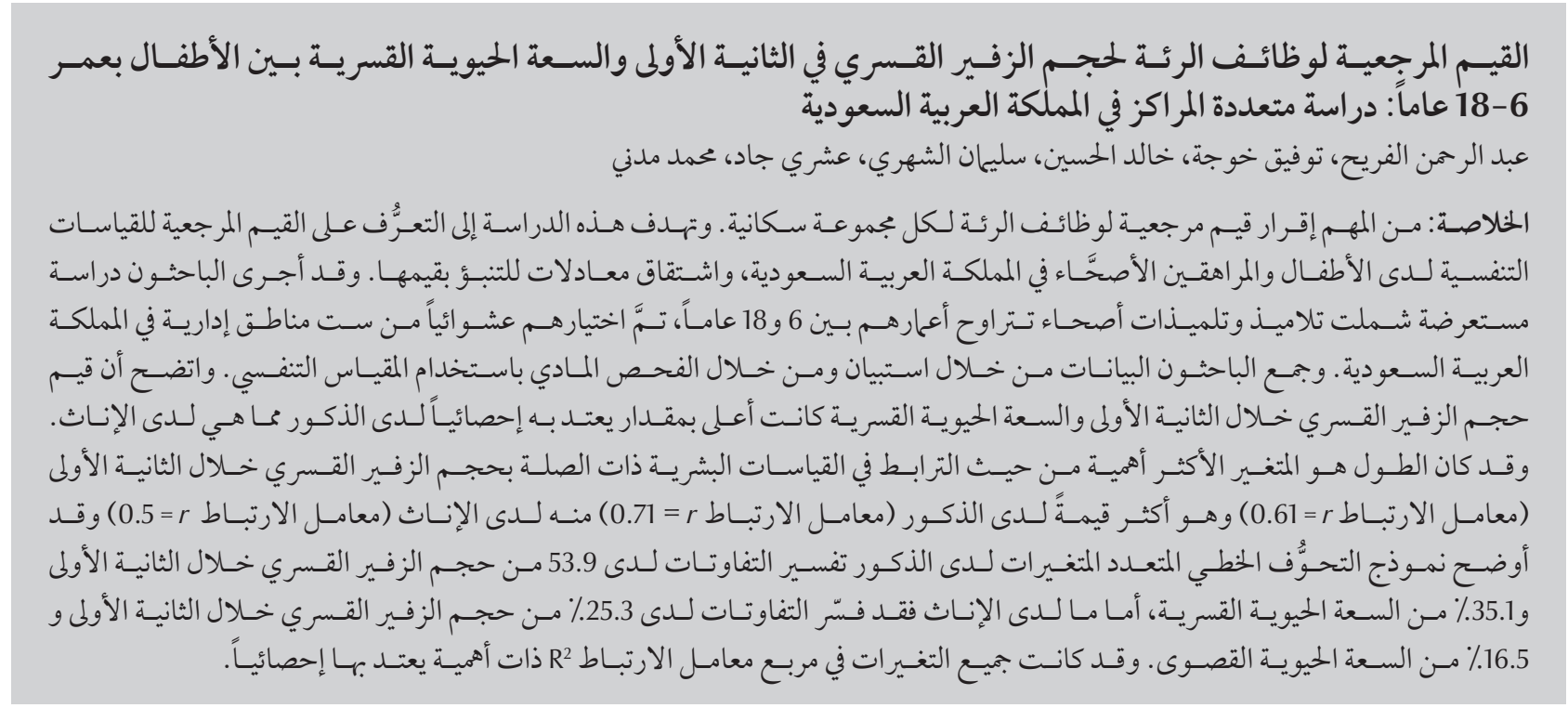

ABSTRACT It is important to establish lung function reference values for each population. This study aimed to determine the spirometric reference values for healthy Saudi Arabian children and adolescents and to derive prediction equations for these. A cross-sectional study was conducted among healthy schoolboys and girls aged 6-18 years old, selected randomly from the 6 administrative regions of Saudi Arabia. Data were collected by questionnaire and physical examinations including spirometry. Forced expiratory volume in 1 second (FEV1) and forced vital capacity (FVC) were significantly higher in males than females. Height was the anthropometric variable most strongly correlated with FEV1 $(r=0.61)$, more so for males $(r=0.71)$ than females $(r=0.50)$. In males the multivariate linear regression model explained $53.9 \%$ of FEV1 and $35.1 \%$ of FVC variations. In females it explained $25.3 \%$ of FEV1 and $16.5 \%$ of FVC variations. All changes in $R^{2}$ were statistically significant.

Valeurs de référence de la VEMS et de la CVF chez des enfants de 6 à 18 ans : étude multicentrique en Arabie saoudite

RÉSUMÉ Il est important d'établir des valeurs de référence de la fonction respiratoire pour chaque population. La présente étude visait à déterminer les valeurs spirométriques de référence chez des enfants et des adolescents saoudiens en bonne santé et à en déduire des équations pronostiques pour ces derniers. Une étude transversale a été menée auprès d'écoliers et d'étudiants des deux sexes en bonne santé et âgés de 6 à 18 ans, sélectionnés aléatoirement dans six régions administratives d'Arabie saoudite. Des données ont été recueillies au moyen d'un questionnaire et d'examens cliniques, y compris la spirométrie. Le volume expiratoire maximal par seconde (VEMS) et la capacité vitale forcée (CVF) étaient nettement supérieurs chez les garçons que chez les filles. La taille était la variable anthropométrique la plus fortement corrélée au VEMS $(r=0,61)$, et cette corrélation était plus forte chez les garçons $(r=0,71)$ que chez les filles $(r=0,50)$. Chez les garçons, le modèle de régression linéaire multivariée expliquait 53,9\% des variations du VEMS et 35,1\% des variations de la CVF. Chez les filles, le modèle expliquait 25,3\% des variations du VEMS et 16,5\% des variations de la CVF. Toutes les évolutions du $R^{2}$ étaient statistiquement significatives. 


\section{Introduction}

Pulmonary function tests have been widely used as an objective measure to diagnose and follow up the course of therapy in lung diseases. Their interpretation is highly dependent on reference values $(1,2)$. Forced expiratory volume in 1 second (FEV1) is widely used to estimate the degree of pulmonary impairment in cases of asthma and other obstructive lung diseases. It has proved to be an excellent method to monitor the progress of individual patients (3).

It is important to establish lung function reference values for each population (4). Lung function differs from one population to other, depending on multiple factors including size and shape of the rib cage, respiratory muscles' strength and possibly parenchymal lung development (5). There are also other influences such as environmental pollution, socioeconomic conditions, nutritional status and exercise, which have direct and indirect effects on lung function (6-8).

Currently available reference values of pulmonary functions tests are mostly based on data from European and North American populations which vary from other populations in body stature and ethnic origin (9). Having local spirometric prediction equations will enhance the reliability of the evaluation of lung function (10). It is therefore important to establish normative values relevant to the ethnic characteristics of the Saudi population.

A literature review yielded only studies among pulmonary patients or adults, but no studies from Saudi Arabia among healthy children (11-13). A study was therefore designed to determine the FEV-1 and forced vital capacity (FCV) reference values for healthy Saudi Arabian children and adolescents and to derive prediction equations for these.

\section{Methods}

\section{Study design and sampling}

This cross-sectional study was conducted among normal healthy schoolboys and schoolgirls aged 6-18 years. It used multistage, stratified random sampling in 6 different city regions in Saudi Arabia selected as sites of the study: Riyadh, Mecca, Dammam, Abha, Jizan and Al-Jouf. Three schools in each region were randomly selected. All children ( $n$ $=5196$ ) registered at the selected schools were invited to participate in the study.

\section{Data collection}

Prior ethical approval and permission of the school health authority were obtained. A pilot study including 20 pupils in the Riyadh region was conducted to test the data collection tools and feasibility of the study. The purpose and objective of the study was explained to the pupils and parents by the school health medical staff prior to conduct of the study. The survey ran from September 2009 to April 2010.

The data were collected by welltrained school health medical staff (including Arabic-speaking physicians and nurses) using a 3-part questionnaire (in Arabic language) Part 1 was age and anthropometric measurements of height in $\mathrm{cm}$ and weight in kg. Part 2 focused on relevant history such as bronchial asthma, skeletal deformity, chronic bronchitis, chest injury, chest surgery cardiac disease, medical treatment for any respiratory condition in the 2 weeks prior to the study, and cigarette smoking. Part 3 was the physical examination performed by the same medical staff who obtained the history. Examinations focused on ear, nose and throat (ENT), chest, abdomen, skin, and any other relevant systems, e.g. cardiac, musculoskeletal systems.
Only Saudi Arabian nationality subjects were recruited. The exclusion criteria were bronchial asthma, chest cage deformities, previous chest injuries and/or chest operation, cardiac surgery, respiratory illness in the last 2 weeks and cigarette smoking (if 5 cigarettes or more per day).

Prior to performing spirometry, the procedure was explained and demonstrated to each child. The pulmonary function test was conducted with the child in a sitting position with the head straight. A minimum of 3 trials were allowed and the best reading was chosen for analysis based on taskforce standard series of the American Task Force standard and European Respiratory Society (14).

Each participant was instructed to take a deep breath and then blow into the mouthpiece as hard and fast as he/she could. The same spirometers were used throughout the study and the tests were performed by the medical staff who were introduced to the study and became acquainted with proper use at the spirometer.

Spirometers used in the study displayed the total valuation of lung function including FVC and FEV1.

\section{Statistical analysis}

The data were analysed using SPSS, version 18. Absolute numbers and proportions were used to describe the sample distribution across the different cities and age groups. Means and standard deviations (SD) were used to describe age and lung functions. Independent $t$-test was used to test the statistical significance of the difference between males and females. Pearson coefficient of correlation $(r)$ was used to investigate the correlation between anthropometric variables and lung functions. Multivariate linear regression model was used to produce coefficient of determination $\left(R^{2}\right)$ and prediction equations were developed. Since lung function data 
from males and females were significantly different, regression analysis was applied to each sex separately.

\section{Results}

Out of 5196 children invited to participate in the present study spirometric tests were done for 4526 (87.1\%); 133 (2.6\%) children refused to participate and $568(11.0 \%)$ were excluded for health reasons [bronchial asthma (75), musculoskeletal diseases (14), smokers (227), cough (161), obesity (26) and ENT problems (34)]. Of the 4526 healthy schoolchildren who agreed to participate in the study 2226 (49.2\%) were males and 2300 (50.8\%) females. Table 1 shows the age and regional distribution of the children by age and sex.

Table 2 shows that while the mean age of females was higher than males [12.8 (SD 3.4) versus 12.5 (SD 3.4) years] the mean height of males was higher than females [145.9 (SD 17.4) versus $144.5(\mathrm{SD} 14.6) \mathrm{cm}$ ]. The differences were statistically significant.

FEV1, FVC and FEV1/FVC were statistically significant higher in males than females $(P<0.001)$ (Table 2$)$. The Pearson correlation coefficients between the anthropometric and pulmonary function measures are shown in Table 3. Height was the highest correlated anthropometric variable with FEV1 $(r=0.61)$. This was true for both males $(r=0.71)$ and females $(r=0.50)$. Age and weight were also correlated with FEV1. All the correlation coefficients were higher for males than females. The same trend was also present in the correlation between anthropometric variables and FVC $(r=$ 0.49 for height, 0.40 for weight and 0.40 for age). All coefficients of correlation were statistically significantly different between males and females $(P<0.05)$.

Multivariate linear regression analysis was done for the anthropometric variables and lung functions in children and adolescents (Table 4). In males the

\begin{tabular}{|c|c|c|c|c|c|c|}
\hline \multicolumn{7}{|c|}{$\begin{array}{l}\text { Table } 1 \text { Demographic characteristics of the studied samp } \\
\text { Arabian children and adolescents, } 2010(n=4526)\end{array}$} \\
\hline \multirow[t]{2}{*}{ Characteristic } & \multicolumn{2}{|c|}{ Males } & \multicolumn{2}{|c|}{ Females } & \multicolumn{2}{|c|}{ Total } \\
\hline & No. & $\%$ & No. & $\%$ & No. & $\%$ \\
\hline \multicolumn{7}{|l|}{ Region } \\
\hline Riyadh & 400 & 18.0 & 426 & 18.5 & 826 & 18.2 \\
\hline Месcа & 190 & 8.5 & 363 & 15.8 & 553 & 12.2 \\
\hline Dammam & 394 & 17.7 & 318 & 13.8 & 712 & 15.7 \\
\hline Abha & 440 & 19.8 & 419 & 18.2 & 859 & 19.0 \\
\hline Jizan & 355 & 15.9 & 420 & 18.3 & 775 & 17.1 \\
\hline Al-Jouf & 447 & 20.1 & 354 & 15.4 & 801 & 17.7 \\
\hline \multicolumn{7}{|l|}{ Age (years) } \\
\hline $6-9$ & 534 & 24.1 & 480 & 21.0 & 1014 & 22.5 \\
\hline $9-12$ & 569 & 25.7 & 603 & 26.4 & 1172 & 26.0 \\
\hline $12-15$ & 591 & 26.7 & 609 & 26.7 & 1200 & 26.7 \\
\hline 15-18 & 523 & 23.6 & 591 & 25.9 & 1114 & 24.8 \\
\hline
\end{tabular}

${ }^{a}$ Age was unknown for 26 students.

model explained $53.9 \%$ of FEV1 and $35.1 \%$ of FVC variations. In females it explained $25.3 \%$ of FEV1 and $16.5 \%$ of FVC variations. In the total studied sample $37.3 \%$ of variation in FEV1 and $24.1 \%$ of FVC were explained by the model. All changes in $R^{2}$ were statistically significant $(P<0.05)$.

The normal values of FEV1 and FVC (between 2.5 and 97.5 percentiles) increased with increases in height in both males and females (Figures 1-4).

\section{Discussion}

Pulmonary function tests are widely used as medical decision-making tools. They are relatively simple and non-invasive, but their interpretation depends on reference values (15). Studies have demonstrated that references values based on European populations may not apply in other populations (16). Development of population-specific spirometric prediction equations is essential to ensure the reliability of lung function evaluation (17).

The present study revealed that the mean FEV1 and FVC were 1.78 (SD $0.75) \mathrm{L}$ and 2.19 (SD 0.98) $\mathrm{L}$ respectively for males and 1.46 (SD 0.68) L and 1.80 (SD 0.92) L respectively for females. A similar study in Jordan included 204 males and 224 females aged 7-18 years and found that the mean

\begin{tabular}{|c|c|c|c|c|c|}
\hline \multirow[t]{2}{*}{ Variable } & \multicolumn{2}{|c|}{$\begin{array}{c}\text { Boys } \\
(n=2226)\end{array}$} & \multicolumn{2}{|c|}{$\begin{array}{c}\text { Girls } \\
(n=2300)\end{array}$} & \multirow[t]{2}{*}{$P$-value } \\
\hline & Mean & (SD) & Mean & (SD) & \\
\hline Age (years) & 12.5 & (3.4) & 12.8 & (3.4) & 0.004 \\
\hline Height (cm) & 145.9 & (17.4) & 144.5 & (14.6) & 0.01 \\
\hline Weight (kg) & 44.1 & (18.9) & 43.3 & (16.0) & 0.129 \\
\hline FEVI (L) & 1.78 & $(0.75)$ & 1.46 & (0.68) & $<0.001$ \\
\hline FVC (L) & 2.19 & $(0.98)$ & 1.80 & (0.92) & $<0.001$ \\
\hline FEVI/FVC & 83.9 & (17.2) & 76.5 & (30.9) & $<0.001$ \\
\hline
\end{tabular}

$S D=$ standard deviation; $F E V 7=$ forced expiratory volume in 1 second; $F C V=$ forced vital capacity. 


\begin{tabular}{|c|c|c|c|c|}
\hline \multirow[t]{2}{*}{ Variable } & \multicolumn{3}{|c|}{ Correlation coefficient } & \multirow[t]{2}{*}{$P$-value } \\
\hline & Males & Females & Total & \\
\hline \multicolumn{5}{|l|}{ FEVI } \\
\hline Height & 0.714 & 0.496 & 0.611 & $<0.001$ \\
\hline Weight & 0.647 & 0.330 & 0.500 & $<0.001$ \\
\hline Age & 0.690 & 0.366 & 0.511 & $<0.001$ \\
\hline \multicolumn{5}{|l|}{ FVC } \\
\hline Height & 0.578 & 0.395 & 0.492 & $<0.001$ \\
\hline Weight & 0.520 & 0.256 & 0.396 & $<0.001$ \\
\hline Age & 0.557 & 0.274 & 0.400 & $<0.001$ \\
\hline \multicolumn{5}{|l|}{$F E V I / F V C$} \\
\hline Height & 0.091 & 0.105 & 0.098 & $<0.001$ \\
\hline Weight & 0.096 & -0.075 & -0.004 & 0.764 \\
\hline Age & 0.092 & 0.011 & 0.032 & 0.035 \\
\hline
\end{tabular}

FEVI = forced expiratory volume in 1 second; $F C V=$ forced vital capacity.

FEV1 ranged from 1.2 to $4.0 \mathrm{~L}$, while FVC ranged from 1.2 to $4.5 \mathrm{~L}$ among children (18). Trabelsi et al. in Tunis reported that the mean FVC was 2.37 (SD 0.81) L and the mean FEV1 was 2.08 (SD 0.7) L for Tunisian children and adolescents aged $6-16$ years (19). The variation in mean values as well prediction equations is widely accepted and attributed to age, sex, body stature, ethnic, genetic and environmental differences (20).

FEV1 and FVC were higher in males than females in the present work. Studies in different parts of the world agreed with this finding. A study conducted at The Aga Khan University Hospital in Pakistan found that mean FEV1 and FVC were higher in males than females in all age groups (9). Manzke et al. reported that the growth pattern is different in males than females and expected that lung function prediction equations should be different for both sexes (21). Their finding was in agreement with the present study results whereby males and females had 2 different prediction equations. Also Thurlbeck in the early 1980s studied the lung morphometry of 36 boys and 20 girls aged 6 weeks to 14 years and found that boys tended to have larger lungs per unit of stature and that the total number of alveoli was greater in males than females (22).

The relationship of anthropometric measurements and values of FEV1 and FCV was assessed by linear logarithmic and power models, but simple linear models were found to be the best predictive equations for lung functions. The present study revealed that height was positively associated with reference values of pulmonary function in children and adolescents. Consistent with this finding Barcala et al. in Spain found that height was the independent variable with the greatest predictive power for lung function (23). Also Vijayan et al. in India reported that among 7-19-year-olds height influences the prediction equations to a greater extent in males than females, but that weight had a greater influence in girls (24). In Hong Kong a study among Chinese children and adolescents has noted that the most important variable affecting the spirometric variables values was height (25). The effect of height may be attributed to the fact that during childhood the lungs increase in proportion to the increase in height and the increase in height leads to an increase in lung volume and

\begin{tabular}{|c|c|c|c|c|c|}
\hline Dependent variable & Intercept & Height & Weight & Age & $R^{2}$ \\
\hline \multicolumn{6}{|l|}{ Males } \\
\hline FEV1 & - & 0.343 & 0.187 & 0.255 & 0.539 \\
\hline FVC & -1.21 & 0.288 & 0.136 & 0.205 & 0.351 \\
\hline FEV1/FVC & 78.45 & 0.001 & 0.063 & 0.046 & 0.010 \\
\hline \multicolumn{6}{|l|}{ Females } \\
\hline FEV1 & -2.49 & 0.650 & -0.129 & -0.074 & 0.253 \\
\hline FVC & -2.71 & 0.566 & -0.109 & -0.108 & 0.165 \\
\hline FEVI/FVC & -30.70 & 0.506 & -0.375 & -0.135 & 0.080 \\
\hline \multicolumn{6}{|l|}{ Total } \\
\hline FEV1 & -2.31 & 0.587 & 0.039 & -0.009 & 0.373 \\
\hline FVC & -2.38 & 0.039 & 0.020 & -0.043 & 0.241 \\
\hline FEVI/FVC & 19.51 & 0.377 & -0.209 & -0.135 & 0.033 \\
\hline
\end{tabular}

$F E V I=$ forced expiratory volume in 1 second; $F C V=$ forced vital capacity. 


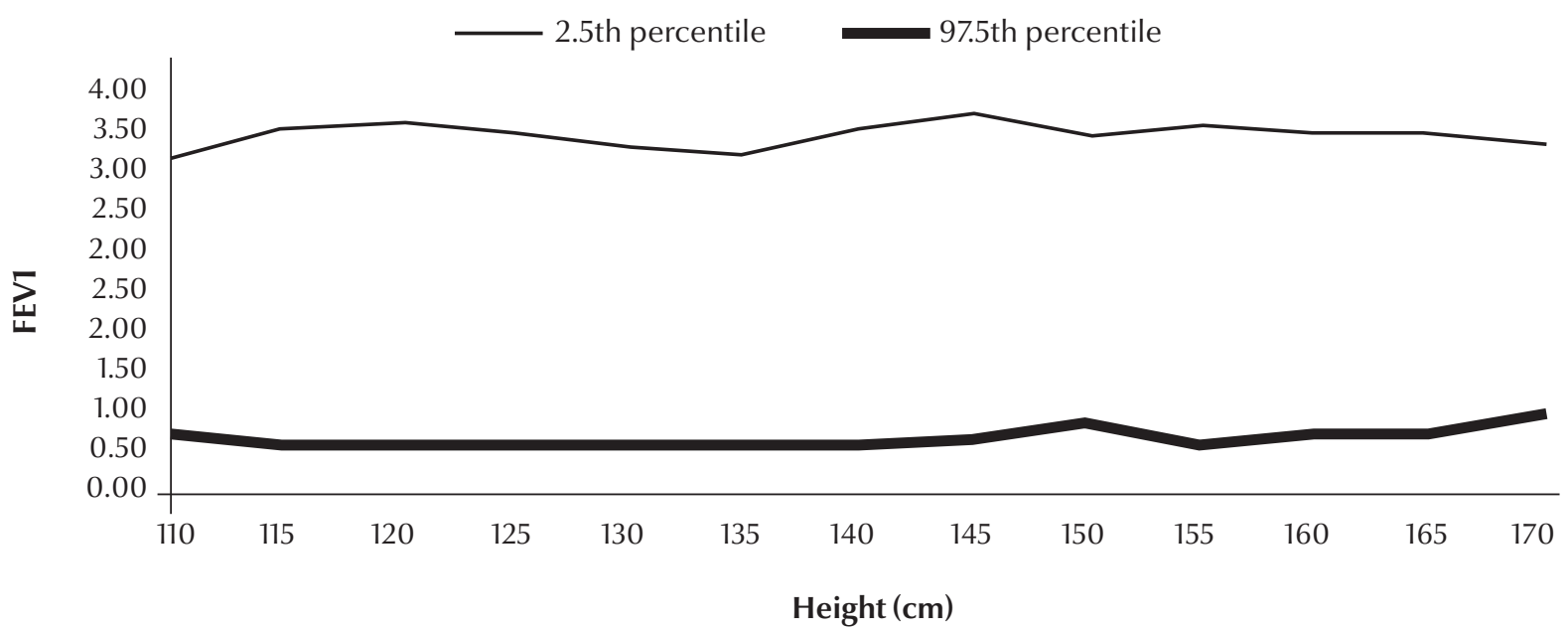

Figure 1 Forced expiratory volume in 1 second (FEV1) chart for Saudi Arabian male children aged 6-18 years old

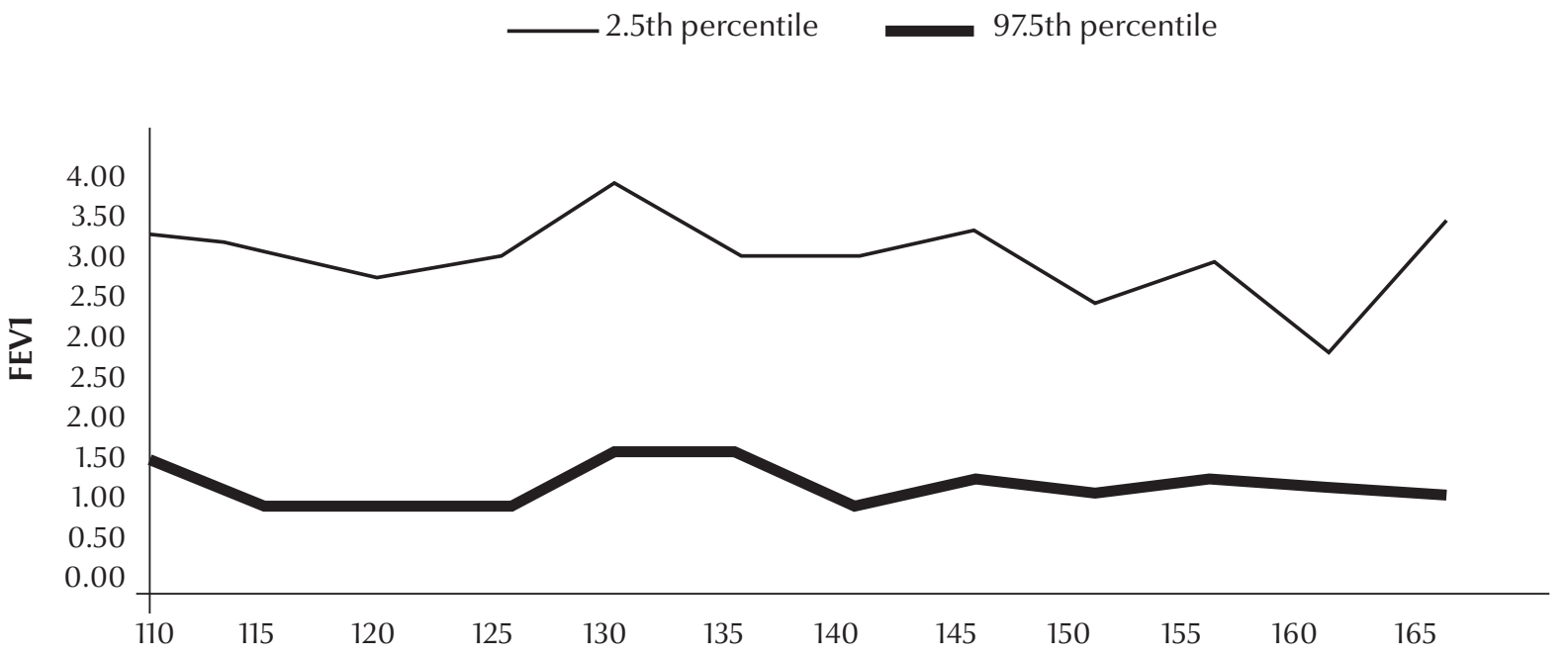

Height (cm)

Figure 2 Forced expiratory volume in $\mathbf{1}$ second (FEV1) chart for Saudi Arabian female children aged 6-18 years old

capacity. Furthermore, height can be accurately measured without the use of special equipment or techniques (26).

The present work shows that age was one of the determinants of spirometric values. Chatterjee and Saha in India reported that age and height were significant predictors of FEV1 and FVC (27). Borsboom et al. studied the pubertal curves of ventilator function and reported that age improved the power of prediction equations because it was correlated with growth and development, particularly the strength of intercostal muscles (28).

The present study had some limitations. It only developed reference values for 2 lung function parameters (FEV1 and FCV). Although 3 schools were selected from each city the number of participants was not equal across cities due to variations in exclusions due to morbidity and refusal to participate among schoolchildren.

\section{Conclusion}

In conclusion, this study has developed normal FEV1 and FCV values and prediction equations for Saudi Arabian children and adolescents (618 years). These national reference values need to be used and tested by health-care providers in Saudi Arabia. A prospective study using repeated measures and including all lung function parameters is recommended among Saudi children. 


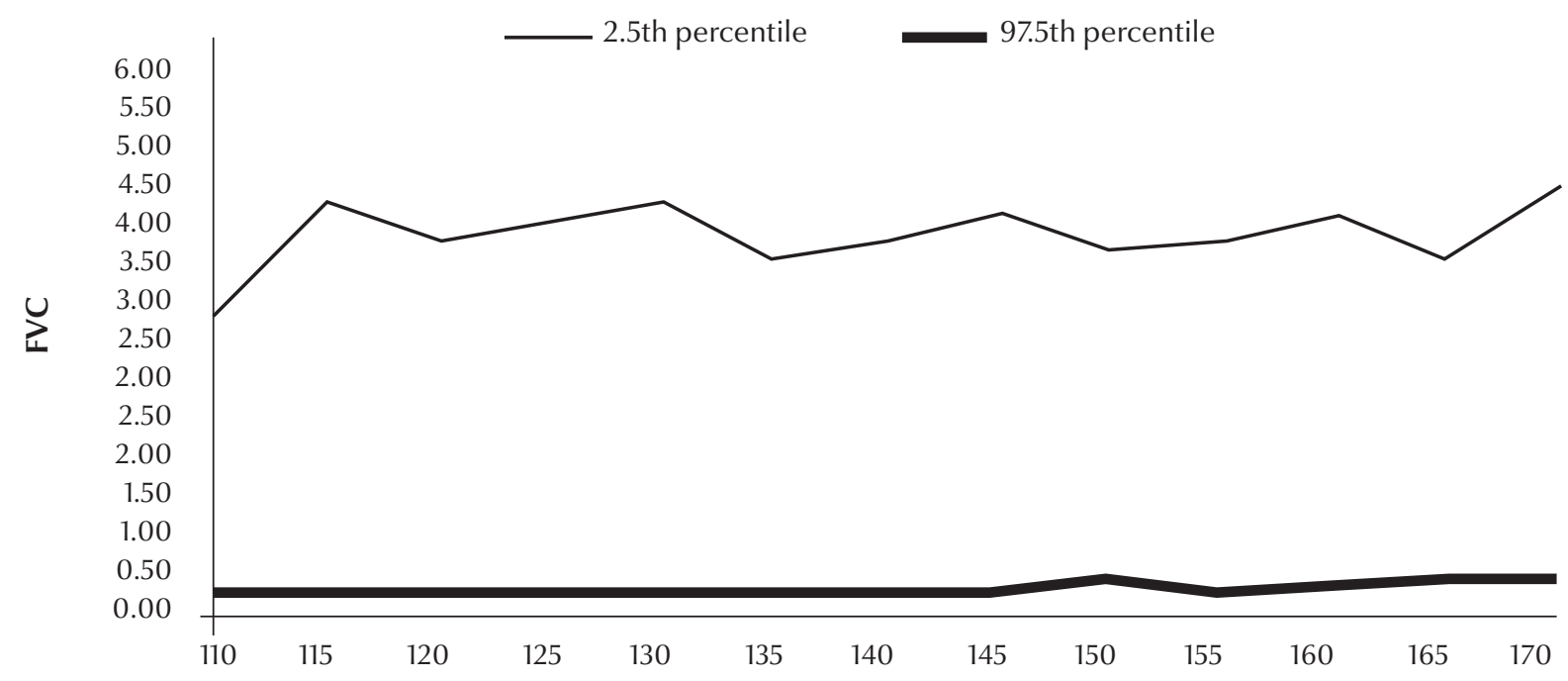

Height (cm)

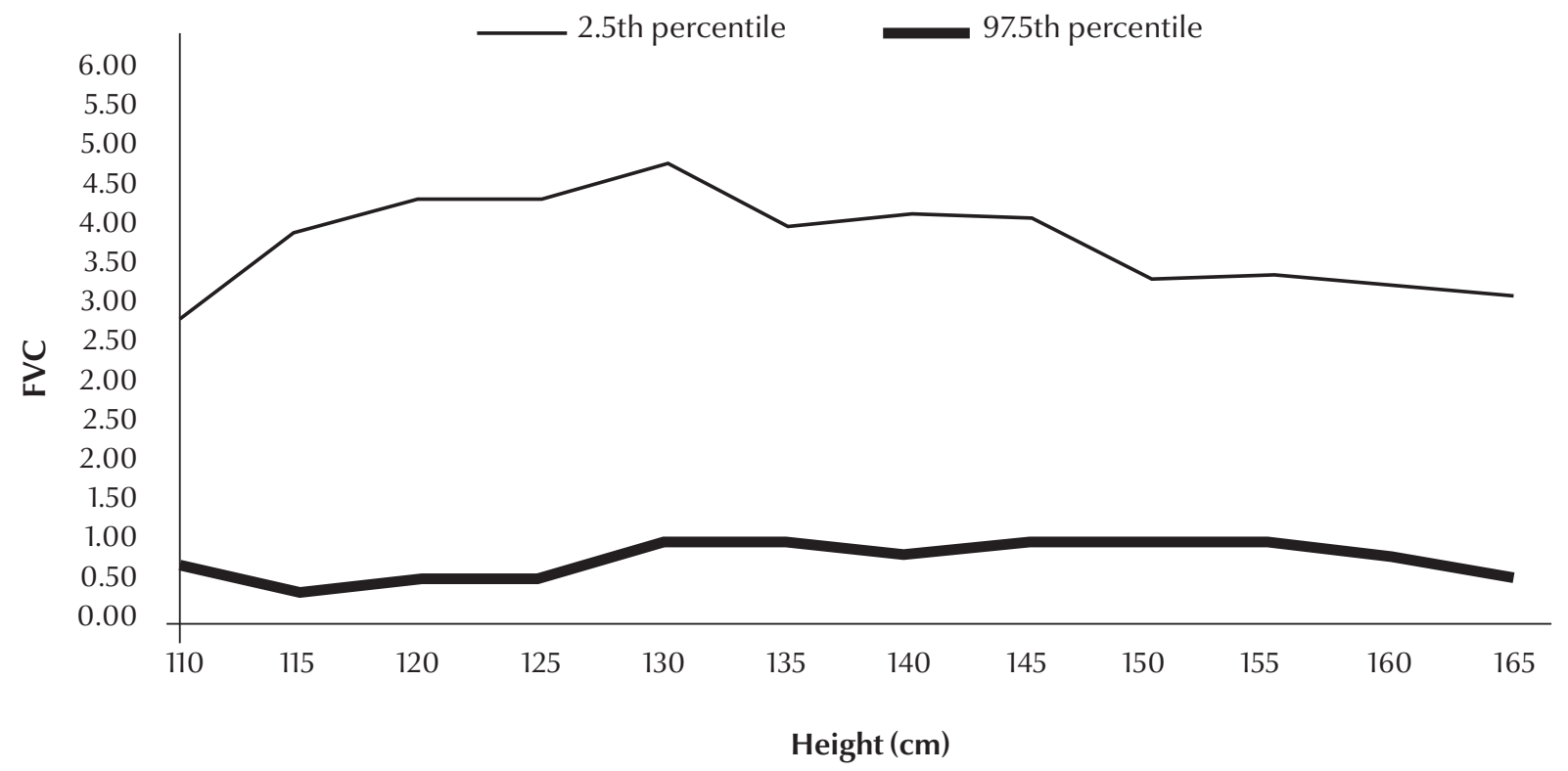

Figure 4 Forced vital capacity (FVC) chart for Saudi Arabian female children aged 6-18 years old

\section{Acknowledgements}

The authors acknowledge and thank the school health physicians and nurses for helping with the data collection. We also thank Professor Mammdouh Al-Messeiry for his assistance in drawing the reference values charts.
Funding: the study was funded by GlaxoSmithKline (GSK), Saudi Arabia.

Competing interests: none declared.

\section{References}

1. Lin FL, Kelso JM. Pulmonary function studies in healthy Filipino adults residing in the United States. J Allergy Clin Immunol. 1999 Aug;104(2 Pt 1):338-40. PMID:10452754
2. Koopman M, Zanen P, Kruitwagen CLJ, Van der Ent CK, Arets HGM. Reference values for paediatric pulmonary function testing: The Utrecht dataset. Respir Med. 2011 Jan;105(1):15-23. 
3. Vaughan TR, Weber RW, Tipton WR, Nelson HS. Comparison of PEFR and FEV1 in patients with varying degrees of airway obstruction. Chest. 1989 Mar;95(3):558-62. PMID:2920583

4. Rochat MK, Laubender RP, Kuster D, Braendli O, Moeller A, Mansmann U, et al. Spirometry reference equations for central European populations from school age to old age. PLoS One. 2013;8(1):e52619. 10.1371/journal.pone.0052619 PMID:23320075

5. Cotes JE. Lung function throughout life: determinants and reference values. In: Cotes JE, editor. Lung Function: Assessment and Application in Medicine. 5th ed. Oxford: Blackwell Scientific Publications; 1993. pp. 445-513.

6. Hankinson JL, Odencrantz JR, Fedan KB. Spirometric reference values from a sample of the general U.S. population. Am J Respir Crit Care Med. 1999 Jan;159(1):179-87. PMID:9872837

7. Ghazal-Musmar S, Musmar M, Minawi WA. Comparison of peak expiratory flow rates applying European and Iranian equations to Palestinian students. East Mediterr Health J. 2010 Apr;16(4):386-90. PMID:20795421

8. Hellmann S, Goren Al. The necessity of building population specific prediction equations for clinical assessment of pulmonary function tests. Eur J Pediatr. 1999 Jun;158(6):519-22. PMID:10378404

9. Ali Baig MI, Qureshi RH. Pulmonary function tests: normal values in non-smoking students and staff at the Aga Khan University, Karachi. J Coll Physicians Surg Pak. 2007 May;17(5):265-8. PMID:17553322

10. Nysom K. ULrik CS, Hesse B, Duksen A. Published models and local data can bridge the gap between reference values of lung function for children and adults. Eur Respir J. 1997;10:1591-8. PMID:9230253

11. Al Ghobain MO, Alhamad EH, Alorainy HS, Al Hazmi M, A Moamary MS, Al-Hajjaj MS, et al. Spirometric reference values for healthy nonsmoking Saudi adults. Clin Respir J. 2014 Jan;8(1):72-8. PMID:23800240

12. Habib SS, Abba AA, Al-Zoghaibi MA, Subhan MM. Reference range values of fractional exhaled nitric oxide in healthy Arab adult males. Saudi Med J. 2009 Nov;30(11):1395-400. PMID:19882049

13. Abdullah AK, Abedin MZ, Nouh MS, Al-Nozha M. Ventilatory function in normal Saudi Arabian adults. Observations and comparison with some Western and Eastern reference values. Trop Geogr Med. 1986 Mar;38(1):58-62. PMID:3961909

14. Miller MR, Hankinson J, Brusasco V, Burgos F, Casaburi R, Coates A, et al.; ATS/ERS Task Force. Standardisation of spirometry. Eur Respir J. 2005 Aug;26(2):319-38. PMID:16055882

15. Horn PS, Pesce AJ. Reference intervals: an update. Clin Chim Acta. 2003 Aug;334(1-2):5-23. PMID:12867273
16. Golshan M, Nematbakhsh M, Amra B, Crapo RO. Spirometric reference values in a large Middle Eastern population. Eur Respir J. 2003 Sep;22(3):529-34. PMID:14516147

17. Pellegrino R, Viegi G, Brusasco V, Crapo RO, Burgos F, Casaburi $R$, et al. Interpretative strategies for lung function tests. Eur Respir J. 2005 Nov;26(5):948-68. PMID:16264058

18. Sliman NA, Dajani BM, Shubair KS. Pulmonary function in normal Jordanian children. Thorax. 1982 Nov;37(11):854-7. PMID:7164005

19. Trabelsi Y, Ben Saad H, Tabka Z, Gharbi N, Bouchez Buvry A, Richalet JP, et al. Spirometric reference values in Tunisian children. Respiration. 2004 Sep-Oct;71(5):511-8. PMID:15467330

20. Bhagyalakshmi O, Prasad CE. Spirometric studies of the subjects in an active area of Hyderabad A.P. Indian J Environ Health. 2002 Apr;44(2):113-7. PMID:14503383

21. Manzke H, Stadlober E, Schellauf HP. Combined body plethysmographic, spirometric and flow volume reference values for male and female children aged 6 to 16 years obtained from "hospital normals". Eur J Pediatr. 2001 May;160(5):300-6. PMID:11388599

22. Thurlbeck WM. Postnatal human lung growth. Thorax. 1982 Aug;37(8):564-71. PMID:7179184

23. González Barcala FJ, Cadarso Suárez C, Valdés Cuadrado L, Leis R, Cabanas R, Tojo R. Valores de referencia de función respiratoria en niños y adolescentes (6-18 años) de Galicia. [Lung function reference values in children and adolescents aged 6 to 18 years in Galicia]. Arch Bronconeumol. 2008 Jun;44(6):295-302. PMID:18559218

24. Vijayan VK, Reetha AM, Kuppurao KV, Venkatesan P, Thilakavathy $\mathrm{S}$. Pulmonary function in normal south Indian children aged 7 to 19 years. Indian J Chest Dis Allied Sci. 2000 JulSep;42(3):147-56. PMID:11089318

25. Ip MS, Karlberg EM, Karlberg JPE, Luk KDK, Leong JCY. Lung function reference values in Chinese children and adolescents in Hong Kong. I. Spirometric values and comparison with other populations. Am J Respir Crit Care Med. 2000 Aug;162(2 Pt 1):424-9. PMID:10934064

26. Ip MS, Karlberg EM, Chan KN, Karlberg JP, Luk KD, Leong JC. Lung function reference values in Chinese children and adolescents in Hong Kong. II. Prediction equations for plethysmographic lung volumes. Am J Respir Crit Care Med. 2000 Aug;162(2 Pt 1):430-5. PMID:10934065

27. Chatterjee S, Saha D. Pulmonary function studies in healthy non-smoking women of Calcutta. Ann Hum Biol. 1993 JanFeb;20(1):31-8. PMID:8422165

28. Borsboom GJ, Van Pelt W, Quanjer PH. Pubertal growth curves of ventilatory function: relationship with childhood respiratory symptoms. Am Rev Respir Dis. 1993 Feb;147(2):372-8. PMID:8430961 